MEDIALOG: Jurnal IImu Komunikasi, Volume III, No. I, Februari 2020, hlm 1-12

\title{
PENGARUH TERPAAN PEMBERITAAN DI MEDIA ONLINE DAN WORD OF MOUTH COMMUNICATIONS TERHADAP PENGAMBILAN KEPUTUSAN DALAM MENGURANGI PENGGUNAAN PLASTIK SAAT BERBELANJA (Survei Pada Pelangan Minimarket Di Denpasar, Bali)
}

\author{
Ilona Vicenovie Oisina Situmeang ${ }^{1}$ \\ ${ }^{1}$ Universitas Persada Indonesia, Jakarta. \\ Email: ilonaoisina@yahoo.com
}

\begin{abstract}
ABSTRAK
Pemberitaan tentang bahaya plastik diharapkan menjadi sumber informasi bagi masyarakat untuk meningkatkan pengetahuan masyarakat akan bahaya limbah plastik bagi lingkungan. Tujuan penelitian untuk mengetahui seberapa besar pengaruh terpaan pemberitaan di media online dan Word Of Mouth Communications terhadap keputusan masyarakat dalam mengurangi penggunaan plastik saat berbelanja. Penelitian ini menggunakan teori Uses and Gratifications, dimana khalayak yang aktif untuk mencari informasi dari berbagai media online. Populasi penelitian adalah pelanggan minimarket di daerah Denpasar sebanyak 100 responden dari tiga minimarket yang terdapat di Denpasar, Bali. Hasil yang diperoleh hubungan sangat kuat antara terpaan pemberitaan di media online terhadap keputusan masyarakat dalam mengurangi penggunaan plastik saat berbelanja koefisien korelasi sebesar 0,888 . Hubungan kuat antara Word of Mouth Communications terhadap keputusan masyarakat dalam mengurangi penggunaan plastik saat berbelanja koefisien korelasi sebesar 0,743. Hasil hubungan kuat antara terpaan pemberitaan di media online dan Word of Mouth Communications terhadap keputusan masyarakat dalam mengurangi penggunaan plastik saat berbelanja dengan koefisien korelasi sebesar 0,709. Hipotesis didapatkan Ha diterima dan Ho ditolak yaitu terdapat pengaruh terpaan pemberitaan di media online dan Word of Mouth Communications terhadap pengambilan keputusan masyarakat dalam mengurangi penggunaan plastik saat berbelanja.
\end{abstract}

Kata Kunci: Pemberitaan di media online, Word of Mouth Communications, keputusan masyarakat, penggunaan plastik, Bali.

\section{THE INFLUENCE OF NEWS REPLACEMENT IN ONLINE MEDIA AND WORD OF MOUTH COMMUNICATIONS ON DECISION MAKING IN REDUCE PLASTIC USE WHEN SHOPPING (Survey of Minimarket Customers in Denpasar, Bali)}

\begin{abstract}
News about the dangers of plastics is expected to be a source of information for the community to increase public knowledge about the dangers of plastic waste to the environment. Delivering messages from people closest to you is one effective way to change people's decisions in reducing the use of plastic, especially when shopping. The purpose of this study was to determine how much influence the news coverage in online media and Word of Mouth Communications on people's decisions to reduce the use of plastic when shopping. This study uses the theory of Uses and Gratifications, where active audiences seek information from various online media. The study population was minimarket customers in the Denpasar area, and used census sampling.

The results obtained there is a very strong relationship between the news in online media to the community's decision to reduce the use of plastic when shopping, the correlation coefficient is 0.888 . There is a strong relationship between Word of Mouth Communications and the community's decision to reduce the use of plastic when shopping, the correlation coefficient is 0.743 . There is a strong relationship between the exposure of news coverage in online media and Word of Mouth Communications to the community's decision to reduce the use of plastic when shopping with a correlation coefficient is 0.709. The hypothesis is that Ha is accepted and Ho is rejected, which is the effect of media coverage on online media and Word of Mouth Communications on community's decision making in reducing the use of plastic when shopping.
\end{abstract}

Keywords: News in online media, Word of Mouth Communication, Community's Decision, The Use of Plastic, Bali 
Korespondensi: Dr. Ilona Vicenovie Oisina. Universitas Persada Indonesia, Jakarta. Jl. Diponegoro No. 74 Jakarta

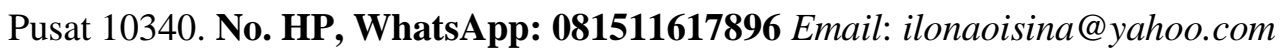

PENDAHULUAN

Media online merupakan salah satu bentuk kemajuan teknologi informasi dan komunikasi yang dapat dinikmati oleh masyarakat dimana dan kapan saja. Terpaan media online berbeda-beda bagi setiap individu. Hal ini disebabkan karena adanya perbedaan pola pikir, sifat yang berdampak pada pengambilan sikap, hubungan sosial sehari-hari, perbedaan pendidikan dan perbedaan budaya. Perubahan sosial dimasyarakat berorientasi pada upaya pembentukan unsur baru, serta berorientasi pada nilai-nilai yang telah ada pada massa lampau. Tanpa sadar media online telah membawa masyarakat masuk kepada pola budaya baru dan mulai menentukan pola pikir serta perilaku masyarakat.

Media online tidak bisa dilepaskan dari denyut nadi kehidupan masyarakat karena efeknya banyak mempengaruhi perilaku masyarakat. Perubahan pola tingkah laku paling terasa ialah dari aspek gaya hidup dan perilaku dari masyarakat. Dampak yang ditimbulkan media online beraneka ragam, tergantung dari intensitas dalam menggunakan media online tersebut. Media online menyediakan berbagai macam berita yang dapat dikonsumsi masyarakat sesuai dengan kebutuhan akan informasi. munculnya media online ini informasi dari sebuah peristiwa akan sangat cepat dapat disampaikan oleh pemilik media kepada masyarakat melalui pemberitaan di media online (Romli \& Syamsul dalam Mustika, 2017)
Dampak yang dirasakan dalam pemberitaan di media online berkaitan erat dengan berita yang diterimanya masyarakat melalui media tersebut. Salah satu berita yang menjadi pusat perhatian bagi masyarakat sampai sekarang ini adalah pemberitaan tentang bahaya dan cara pengurangan penggunaan plastik dalam kehidupan sehari-hari, Jika diperhatikan pengerusakan lingkungan terus saja dilakukan oleh manusia dan sangat sulit untuk dikurangin. Penebangan hutan, buang sampah sembarangan, pencemaran aliran sungai, serta penggunaan plastik yang berlebihan yang sulit untuk diurai oleh alam. Dampak yang dirasakan oleh manusia saat ini seperti terjadinya bencana banjir, longsor, dan banyaknya penyakit yang timbul karena sampah seperti penyakit kulit dan gangguan pernafasan.

Salah satu yang sulit untuk dihindari oleh manusia tidak dapat terlepas dari penggunaan plastik dalam kehidupan sehari-hari. Mulai dari penggunaan plastik belanjaan, botol kosmetik, botol minuman, hingga perangkat elektronik di rumah meggunakan komponen plastik. Saat ini sampah plastik yang terbuang ke lautan sebesar 13,9 juta ton pada hasil riset di tahun 2010, Indonesia menempati negara nomor 2 dari 20 negara terbanyak yang membuang sampah plastik ke laut, nomor 1 di tempati oleh Republik Rakyat Tiongkok. (Bhuwananda dalam Situmeang dan Girsang, 2016).

Penggunaan plastik yang berlebihan menyebabkan ekosistem tidak dapat berfungsi 
dengan baik, dikarenakan sampah plastik baru benar bersih terurai minimal 500 tahun secara sempurna. Berkaca dari hal seperti itu maka kepedulian pemerintah bersama masyarakat tentang peduli lingkungan hidup harus serius dilakukan seperti kampanye, iklan layanan masyarakat dan sosialisasi kepada isu lingkungan untuk mengurangi penggunaan sampah plastik dan mendesak industri untuk mengolah kembali sampah plastik. Selain itu sistem pengolahan sampah yang kurang maju, kesadaran masyarakat untuk tidak membuang sampah sembarangan menjadikan lingkungan menjadi rentan dengan penumpukan sampah plastik (Situmeang dan Girsang, 2016).

Sampah plastik akan berdampak negatif terhadap lingkungan karena dapat menurunkan kesuburan tanah. Sampah plastik yang dibuang sembarangan juga dapat menyumbat saluran drainase, selokan dan sungai sehingga bisa menyebabkan banjir. Sampah plastik yang dibakar bisa mengeluarkan zat-zat yang berbahaya bagi kesehatan manusia. Semakin meningkatnya sampah plastik ini akan menjadi masalah serius bila tidak dicari penyelesaiannya. Penanganan sampah plastik yang populer selama ini adalah dengan 3R (Reuse, Reduce, Recycle). Reuse adalah memakai berulang kali barangbarang yang terbuat dari plastik. Reduce adalah mengurangi pembelian atau penggunaan barang-barang dari plastik, terutama barang-barang yang sekali pakai. Recycle adalah mendaur ulang barang-barang yang terbuat dari plastik (Surono, 2013).
Berbagai pemberitaan sampah plastik di media menunjukkan bahwa pemerintah dan para pemerhati lingkungan gencar dalam membuat berita untuk mengajak masyarakat mengurangi penggunaan sampah plastik. Berita yang dibuat semenarik mungkin untuk menimbulkan rasa ingin tahu masyarakat dan mengedukasi masyarakat tentang sampah plastik, penghematan menggunakan sampah plastik serta mendaur ulang sampah plastik. Iklan layanan masyarakat mengilustrasikan sampah yang dipergunakan oleh manusia tidak hanya merugikan dirinya sendiri namun juga orang disekitar dan bahkan mahluk hidup yang ada pada lingkungan tersebut (Situmeang dan Girsang, 2016).

Untuk menyadarkan masyarakat akan pentingnya pengurangan penggunaan sampah plastik harus didukung berbagai pihak dalam pemberitaan melalui media cetak, elektronik dan online dengan penggunaan iklan layanan masyarakat di berbagai media komunikasi. Selain itu juga diharapkan adanya sosialisali yang rutin dilakukan untuk mengingatkan kembali masyarakat dalam menggunakan plastik. Dampak penggunakan sampah plastik bagi kehidupan dimasa yang akan datang dan keberlanjutan ekosistem. Pemberitaan yang terus dilakukan akan menyadarkan masyarakat untuk bersama-sama menjaga lingkungan dan mengurangi pemakaian plastik (Situmeang dan Girsang, 2016).

Denpasar, Bali merupakan salah satu wilayah yang benar-benar memberlakukan pelarangan peggunaan plastik saat berbelanja. Tidak menyediakan plastik sebagai wadah dalam 
berbelanja. Gubernur Bali Wayan Koster mengumumkan larangan penggunaan kantong plastik, styrofoam dan sedotan plastik, Senin, 24 Desember 2018. Larangan yang dicantumkan dalam Peraturan Gubernur (Pergub) nomor 97 tahun 2018 itu untuk menekan sampah plastik yang diharapkan bisa mencapai 70 persen dalam satu tahun mendatang. "Itu sesuai visi menjaga kesucian alam Bali dan untuk mempertahankan kualitas industri pariwisata," (TEMPO.Co, Denpasar, Senin, 24 Desember 2018 11:32 WIB).

Limbah sampah plastik menimbulkan masalah bagi lingkungan, Pakar lingkungan dan ilmuwan dari berbagai disiplin ilmu telah melakukan berbagai penelitian dan tindakan. Salah satu dengan cara mendaur ulang limbah plastik. Namun, cara ini tidak terlalu efektif. Hanya sekitar $4 \%$ yang dapat didaur ulang, sisanya menggunung di tempat penampungan sampah (Kadir, 2012).

Diharapkan dengan pemberitaan melalui media online menimbulkan rasa kepedulian masyarakat akan pentingnya menjaga kualitas lingkungan agar tetap bersahabat dengan kehidupan manusia, apalagi Bali menjadi barometer pariwisata di Indonesia. Masyarakat dengan rasa peduli terus melakukan word of mouth communications kepada orang-orang terdekat untuk terus mengurangi penggunaan plastik. Informasi yang disampaikan melalui Word of mouth commuications lebih efektif dan lebih mudah berpengaruh terhadap pengambilan keputusan terhadap sesuatu hal dibandingkan dengan promosi melalui iklan.
Dalam penelitian ini penulis melihat seberapa besar terpaan berita pada media online sebagai saluran penyampai informasi yang sering digunakan masyarakat dan kegiatan word of mouth communications yang menimbulkan dampak positif bagi masyarakat dalam penyebaran informasi tentang pengurangan penggunaan plastik dalam berbelanja untuk menjaga keberlangsungan ekosistem dan lingkungan tempat tinggal. Diharapkan melalui pemberitaan melalui media online dan kegiatan word of mouth communications menjadikan penambahan pengetahuan bagi masyarakat khususnya daerah Denpasar, Bali agar dapat melakukan pengambilan keputusan untuk tidak menggunakan plastik saat berbelanja. Hal ini merupakan salah satu cara yang paling efektif untuk mengurangi sampah plastik yang tidak dapat didaur ulang hingga ratusan tahun.

Selama ini minimarket menyediakan kantong plastik berbayar dengan bayaran yang sangat terjangkau yaitu Rp 200,- untuk 1 buah kantong plastik. Cara ini dianggap tidak efektif untuk mengurangi pemakaian plastik saat berbelanja. Sehingga untuk setiap penjualan didaerah Denpasar Bali, tidak menyediakan kantong plastik berbayar. Dari penjelasan fenomena diatas penulis memiliki keinginan untuk meneliti tentang pengaruh terpaan pemberitaan di media online dan word of mouth communications terhadap pengambilan keputusan dalam pengurangan penggunaan plastik saat berbelanja. 


\section{METODE PENELITIAN}

\section{A. Jenis Penelitian}

Pendekatan penelitian ini adalah pendekatan kuantitatif. Pendekatan kuantitatif menurut Kriyantono (2007) adalah riset yang menggambarkan atau menjelaskan suatu masalah yang hasilnya dapat digeneralisasikan. Penelitian kuantitatif dimulai dengan kegiatan menjajaki permasalahan yang menjadi pusat perhatian peneliti. Kemudian peneliti mendefinisikan dan memformulasikan masalah penelitian dengan jelas, sehingga mudah dimengerti. Setelah masalah penelitian diformulasikan, maka didesain rancangan penelitian yaitu desain model penelitian, desain inilah yang nantinya menuntun pelaksanaan penelitian secara keseluruhan (Bungin, 2008).

Mengacu pada tujuan penelitian, peneliti berusaha mencari hubungan antar variabel yang terkait dengan terpaan pemberitaan di media online dan word of mouth communications terhadap pengambilan keputusan masyarakat dalam mengurangi penggunaan plastik saat berbelanja. Untuk mencapai tujuan tersebut, peneliti merancang penelitian ini sebagai survei dengan penelitian menerangkan (explanatory research) dengan penelitian deskriptif (descriptive research).

Rancangan ini sesuai dengan pendapat Babbie (1992) yang menyatakan bahwa penelitian yang bertipe menerangkan adalah, penelitian yang bertujuan menjelaskan pengaruh dan hubungan antar variabel melalui pengujian hipotesis.
Unit analisis dalam penelitian ini adalah masyarakat yang menjadi pelanggan beberapa minimarket yang ada di Denpasar, Bali.

Populasi dan Sampel

Populasi adalah kumpulan semua (orang, perusahaan) yang dipertimbangkan dengan baik. Karakteristik penting dari populasi adalah berisi semua elemen yang menarik perhatian. Populasi dapat dibatasi atau tidak dalam hal ukuran (Ashenfelter et al., 2003).

Dalam penelitian ini yang menjadi populasi adalah masyarakat yang menjadi pelanggan beberapa minimarket yang ada di Denpasar, Bali sebanyak 100 responden.

Pemilihan sampel ini merupakan hal yang sangat penting. Berbagai metode pengambilan sampel tersedia namun hal kunci yang harus diingat bahwa sampel sebuah populasi dapat menggambarkan populasi (Ashenfelter et al., 2003). Dalam penelitian ini penulis menetapkan jumlah sampel untuk pretest sebanyak 30 orang responden. Untuk penelitian besar menggunakan sensus mengambil jumlah populasi sama dengan sampel yang menjadi pelanggan beberapa minimarket di Denpasar, Bali sebanyak 100 responden.

\section{B. Instrumen Penelitian}

\section{Operasionalisasi Variabel}

Variabel XI: Terpaan Media

\section{Dimensinya:}

1. Penggunaan media,

2. Jenis media,

3. Frekuensi penggunaan (frequency),

4. Durasi penggunaan (longevity). 
Variabel X2: Word of Mouth Communications

Dimensinya:

1. Talkers (pembicara),

2. Topics (topik),

3. Tools (alat),

4. Talking part (partisipasi),

5. Tracking (pengawasan).

Varianel X3: Pengambilan Keputusan

Dimensinya:

1. Masalah yang dihadapi,

2. Pegetahuan,

3. Fakta dan data,

4. Alternative pilihan,

5. Menjatuhkan pilihan.

\section{Teknik Analisis Data}

\section{Analisis Korelasi}

Peneliti menganalisis data yang diperoleh melalui kuesioner. Rumus atau teknik statistik yang digunakan untuk mengetahui koefisien korelasi atau derajat kekuatan hubungan dan membuktikan hipotesis hubungan antara variabel atau data atau skala interval dengan interval lainnya yaitu dengan menggunakan teknik korelasi Pearson's Product Moment (Kriyantono, 2007).

\section{Analisis Regresi}

Analisis regresi ditujukan untuk mencari bentuk hubungan dua variabel atau lebih dalam bentuk fungsi atau persamaan (Kriyantono, 2007). Untuk meriset apakah memang ada pengaruh antara variabel $\mathrm{X}$ dengan Variabel $\mathrm{Y}$ maka digunakan rumus Regresi Linear sederhana. Penulis menggunakan Regresi Linear sederhana karena sudah diketahui variabel $\mathrm{X}$ adalah variabel bebas dan variabel $\mathrm{Y}$ adalah variabel terikat dimana nilai-nilai $\mathrm{Y}$ dapat dihitung berdasarkan nilai $\mathrm{X}$ tertentu.

\section{Uji F dan Uji T}

Analisis $\mathrm{T}$ dan $\mathrm{F}$ dilakukan untuk melihat terdapat pengaruh diantara variabel yang diteliti untuk menjawab dari hipotesis penelitian yang ada.

\section{HASIL DAN PEMBAHASAN}

\section{Hasil Uji Validitas}

Tabel 1: Validitas Variabel X1

\begin{tabular}{|c|c|c|c|}
\hline Pernyataan & $\begin{array}{c}\text { Nilai R } \\
\text { Tabel }\end{array}$ & $\begin{array}{c}\text { Nilai } \\
\mathbf{R} \\
\text { Hitung }\end{array}$ & Keterangan \\
\hline P1 & 0,361 & 0,467 & VALID \\
\hline P2 & 0,361 & 0,881 & VALID \\
\hline P3 & 0,361 & 0,549 & VALID \\
\hline P4 & 0,361 & 0.713 & VALID \\
\hline P5 & $\mathbf{0 , 3 6 1}$ & $\mathbf{0 , 1 2 6}$ & DROP \\
\hline P6 & 0,361 & 0,551 & VALID \\
\hline P7 & 0,361 & 0,632 & VALID \\
\hline P8 & $\mathbf{0 , 3 6 1}$ & $\mathbf{0 , 2 7 4}$ & DROP \\
\hline
\end{tabular}

Sumber: Hasil olah data penulis

Hasil pretest variabel $\mathrm{X} 1$ diperoleh nilai tabel 30 responden: 0,361. Untuk mendapatkan keterangan valid maka nilai $\mathrm{r}$ hitung $>$ nilai $\mathrm{r}$ tabel, sehingga didapatkan hasil dari 8 pernyataan sebanyak 2 pernyataan dinyatakan DROP dan 6 pernyataan dinyatakan VALID akan digunakan untuk penelitian selanjutnya.

Tabel 2: Validitas Variabel X2

\begin{tabular}{|c|c|c|c|}
\hline Pernyataan & $\begin{array}{c}\text { Nilai R } \\
\text { Tabel }\end{array}$ & $\begin{array}{c}\text { Nilai } \\
\mathbf{R} \\
\text { Hitung }\end{array}$ & Keterangan \\
\hline P1 & 0,361 & 0,457 & VALID \\
\hline P2 & 0,361 & 0,399 & VALID \\
\hline P3 & 0,361 & 0,561 & VALID \\
\hline P4 & $\mathbf{0 , 3 6 1}$ & $\mathbf{0 , 1 9 6}$ & DROP \\
\hline P5 & 0,361 & 0,502 & VALID \\
\hline P6 & 0,361 & 0,375 & VALID \\
\hline P7 & 0,361 & 0,446 & VALID \\
\hline P8 & 0,361 & 0.501 & VALID \\
\hline P9 & 0,361 & 0,577 & VALID \\
\hline P10 & 0,361 & 0,428 & VALID \\
\hline
\end{tabular}

Sumber: Hasil olah data penulis 
Hasil pretest variabel X2 diperoleh nilai tabel untuk 30 responden adalah 0,361. Untuk mendapatkan keterangan valid maka nilai $r$ hitung $>$ nilai $\mathrm{r}$ tabel, sehingga didapatkan hasil dari 10 buah pernyataan sebanyak 1 buah pernyataan dinyatakan valid dan 9 buah pernyataan dinyatakan DROP, yang VALID akan digunakan untuk penelitian selanjutnya.

Tabel 3: Validitas Variabel Y

\begin{tabular}{|c|c|c|c|}
\hline Pernyataan & $\begin{array}{c}\text { Nilai R } \\
\text { Tabel }\end{array}$ & $\begin{array}{c}\text { Nilai } \\
\mathbf{R} \\
\text { Hitung }\end{array}$ & Keterangan \\
\hline P1 & 0,361 & 0,501 & VALID \\
\hline P2 & 0,361 & 0,467 & VALID \\
\hline P3 & 0,361 & 0.663 & VALID \\
\hline P4 & 0,361 & 0,702 & VALID \\
\hline P5 & 0,361 & 0,825 & VALID \\
\hline P6 & 0,361 & 0,409 & VALID \\
\hline P7 & 0,361 & 0,694 & VALID \\
\hline P8 & 0,361 & 0,773 & VALID \\
\hline P9 & $\mathbf{0 , 3 6 1}$ & $\mathbf{0 , 2 1 9}$ & DROP \\
\hline P10 & 0,361 & 0,795 & VALID \\
\hline
\end{tabular}

Sumber: Hasil olah data penulis

Hasil pretest variabel $\mathrm{Y}$ diperoleh nilai tabel untuk 30 responden adalah 0,361. Untuk mendapatkan keterangan valid maka nilai $r$ hitung $>$ nilai $\mathrm{r}$ tabel, sehingga didapatkan hasil dari 10 buah pernyataan sebanyak 1 pernyataan dinyatakan DROP dan sebanyak 9 pernyataan dinyatakan VALID yang akan digunakan untuk penelitian selanjutnya.

\section{Hasil Uji Reliabilitas}

Tabel 4: Reliability X1

\begin{tabular}{|c|c|}
\hline $\begin{array}{c}\text { Cronbach's } \\
\text { Alpha }\end{array}$ & $\mathrm{N}$ of Items \\
\hline .873 & 8 \\
\hline
\end{tabular}

Dari tabel di atas, diketahui bahwa nilai Cronbach's Alpha untuk variabel X1 adalah 0,873. Oleh karena nilai Cronbach's Alpha berada diatas 0,60, maka dapat disimpulkan bahwa setiap item pertanyaan untuk mendapatkan nilai variabel X1 dapat dinyatakan reliabel.

Tabel 5: Reliability X2

\begin{tabular}{|c|c|}
\hline $\begin{array}{c}\text { Cronbach's } \\
\text { Alpha }\end{array}$ & $\mathrm{N}$ of Items \\
\hline .895 & 10 \\
\hline
\end{tabular}

Dari tabel di atas, diketahui nilai Cronbach's Alpha untuk variabel X2 adalah 0,895. Karena nilai Cronbach's Alpha berada diatas 0,60, maka dapat disimpulkan bahwa setiap item pertanyaan untuk mendapatkan variabel X2 dapat dinyatakan reliabel.

Tabel 6: Reliability Y

\begin{tabular}{|r|r|}
\hline $\begin{array}{c}\text { Cronbach's } \\
\text { Alpha }\end{array}$ & N of Items \\
\hline .912 & 10 \\
\hline
\end{tabular}

Sumber: Hasil olah data penulis

Dari tabel di atas, diketahui bahwa nilai Cronbach's Alpha untuk variabel Y adalah 0,912. Oleh karena nilai Cronbach's Alpha berada diatas 0,60, maka dapat disimpulkan bahwa setiap item pertanyaan untuk mendapatkan variabel Y dapat dinyatakan reliabel.

\section{ANALISIS DATA}

\section{Hasil Analisis Korelasi}

Tabel 7: Correlations

\begin{tabular}{|c|c|c|c|c|}
\hline & & $\begin{array}{c}\text { TERPAAN } \\
\text { BERITA }\end{array}$ & $\begin{array}{l}\text { WORD } \\
\text { OF } \\
\text { MOUTH }\end{array}$ & $\begin{array}{l}\text { PENGAMBIL } \\
\text { AN } \\
\text { KEPUTUSAN }\end{array}$ \\
\hline \multirow[t]{3}{*}{$\begin{array}{l}\text { Pearson } \\
\text { Correlation }\end{array}$} & $\begin{array}{l}\text { TERPAAN } \\
\text { BERITA }\end{array}$ & 1.000 & .876 & .888 \\
\hline & $\begin{array}{l}\text { WORD OF } \\
\text { MOUTH }\end{array}$ & .876 & 1.000 & .743 \\
\hline & $\begin{array}{l}\text { PENGAMB } \\
\text { ILAN } \\
\text { KEPUTUS } \\
\text { AN }\end{array}$ & .888 & .743 & 1.000 \\
\hline Sig. (1-tailed) & $\begin{array}{l}\text { TERPAAN } \\
\text { BERITA } \\
\text { WORD OF } \\
\text { MOUTH } \\
\text { PENGAMB } \\
\text { ILAN } \\
\text { KEPUTUS } \\
\text { AN }\end{array}$ & .000 & .000 & $\begin{array}{l}.000 \\
.000\end{array}$ \\
\hline \multirow[t]{2}{*}{$\mathrm{N}$} & $\begin{array}{l}\text { TERPAAN } \\
\text { BERITA }\end{array}$ & 100 & 100 & 100 \\
\hline & $\begin{array}{l}\text { WORD OF } \\
\text { MOUTH }\end{array}$ & 100 & 100 & 100 \\
\hline
\end{tabular}


Tabel 7: Correlations

\begin{tabular}{|c|c|c|c|c|}
\hline & & $\begin{array}{l}\text { TERPAAN } \\
\text { BERITA }\end{array}$ & $\begin{array}{c}\text { WORD } \\
\text { OF } \\
\text { MOUTH }\end{array}$ & $\begin{array}{l}\text { PENGAMBIL } \\
\text { AN } \\
\text { KEPUTUSAN }\end{array}$ \\
\hline \multirow[t]{3}{*}{$\begin{array}{l}\text { Pearson } \\
\text { Correlation }\end{array}$} & $\begin{array}{l}\text { TERPAAN } \\
\text { BERITA }\end{array}$ & 1.000 & .876 & .888 \\
\hline & $\begin{array}{l}\text { WORD OF } \\
\text { MOUTH }\end{array}$ & .876 & 1.000 & .743 \\
\hline & $\begin{array}{l}\text { PENGAMB } \\
\text { ILAN } \\
\text { KEPUTUS } \\
\text { AN }\end{array}$ & .888 & .743 & 1.000 \\
\hline \multirow[t]{4}{*}{ Sig. (1-tailed) } & $\begin{array}{l}\text { TERPAAN } \\
\text { BERITA }\end{array}$ & & .000 & .000 \\
\hline & $\begin{array}{l}\text { WORD OF } \\
\text { MOUTH }\end{array}$ & .000 & & .000 \\
\hline & PENGAMB & .000 & .000 & \\
\hline & $\begin{array}{l}\text { ILAN } \\
\text { KEPUTUS } \\
\text { AN }\end{array}$ & & & \\
\hline \multirow[t]{3}{*}{$\mathrm{N}$} & $\begin{array}{l}\text { TERPAAN } \\
\text { BERITA }\end{array}$ & 100 & 100 & 100 \\
\hline & $\begin{array}{l}\text { WORD OF } \\
\text { MOUTH }\end{array}$ & 100 & 100 & 100 \\
\hline & $\begin{array}{l}\text { PENGAMB } \\
\text { ILAN } \\
\text { KEPUTUS } \\
\text { AN }\end{array}$ & 100 & 100 & 100 \\
\hline
\end{tabular}

Sumber: Hasil olah data penulis

Dari tabel hasil uji korelasi dapat disimpulkan menjadi 3 poin :

1. Terdapat hubungan antara variabel $\mathrm{X} 1$ dan $\mathrm{Y}$, hal ini dapat dilihat dari nilai Sig yang menunjukan nilai 0,000 dimana nilai tersebut lebih kecil dari 0,05. Hubungan antara kedua variabel tersebut adalah hubungan yang positif, yang artinya apabila terdapat peningkatan pada variabel Terpaan pemberitaan maka pengambilan keputusan juga akan mengalami peningkatan. Nilai koefisien korelasi Pearson Correlation sebesar 0,888. Tingkat hubungan antara kedua variabel termasuk dalam korelasi sangat kuat, karena berada dalam interval 0,800-0,999 dengan tingkat hubungan sangat kuat.

2. Terdapat hubungan antara variabel $\mathrm{X} 2$ dan $\mathrm{Y}$, hal ini dapat dilihat dari nilai Sig yang menunjukan nilai 0,000 dimana nilai tersebut lebih kecil dari 0,05. Hubungan antara kedua variabel tersebut adalah hubungan yang positif, yang artinya apabila terdapat peningkatan pada variabel word of mouth communications maka pengambilan keputusan juga akan mengalami peningkatan. Nilai koefisien korelasi Pearson Correlation sebesar 0,743. Tingkat hubungan kedua variabel termasuk dalam korelasi kuat, karena berada dalam interval 0,60-0,799 dengan tingkat hubungan kuat.

Hasil Analisis Korelasi Berganda TABEL 8: ANALISIS KORELASI BERGANDA

\begin{tabular}{|c|c|c|c|c|}
\hline Model & $\mathrm{R}$ & $\begin{array}{c}\mathrm{R} \\
\text { Square }\end{array}$ & $\begin{array}{c}\text { Adjusted } \\
\mathrm{R} \text { Square }\end{array}$ & $\begin{array}{c}\text { Std. } \\
\text { Error of } \\
\text { the } \\
\text { estimate }\end{array}$ \\
\hline 1 & $.902 \mathrm{a}$ &, 901 &, 904 & 2.22430 \\
\hline \multicolumn{4}{|c}{ Sumber: Hasil olah data penulis }
\end{tabular}

Koefisien korelasi menunjukkan kuat tidaknya pengaruh variabel independen (terpaan pemberitaan media online dan word of mouth communications) terhadap variabel dependen (pengambilan keputusan). Dari hasil perhitungan didapat nilai korelasi (R) sebesar 0,902 atau 90,2\% yang hampir mendekati nilai 1. Artinya bahwa variabel independen memiliki pengaruh yang cukup kuat terhadap variabel dependen. Ini berarti bahwa terpaan pemberitaan media online dan word of mouth communications memberikan pengaruh yang sangat kuat bagi pengambilan keputusan bagi pelanggan dalam berbelanja.

\section{Uji Regresi Berganda}

Tabel 9: Hasil Uji Regresi Berganda

\begin{tabular}{|l|r|r|r|r|r|}
\hline \multicolumn{1}{|c|}{ Model } & \multicolumn{2}{|c|}{$\begin{array}{c}\text { Unstandardized } \\
\text { Coefficients }\end{array}$} & $\begin{array}{c}\text { Standar } \\
\text { dized } \\
\text { Coeffici } \\
\text { ents }\end{array}$ & \multicolumn{1}{|c|}{ T } & Sig \\
\cline { 2 - 4 } & $\mathbf{B}$ & $\begin{array}{c}\text { Std } \\
\text { Eror }\end{array}$ & B & & \\
\hline 1 (Constant) & 3.324 & 1.629 & & 1.972 & 0.51 \\
\hline $\begin{array}{l}\text { Terpaan } \\
\text { Pemberitaan }\end{array}$ & .802 & .051 & .818 & 16.822 & .000 \\
\hline $\begin{array}{l}\text { Word of } \\
\text { Mouth }\end{array}$ & .226 & .038 & .160 & 3.085 & .003 \\
\hline
\end{tabular}

Sumber: Hasil olah data penulis 
Tabel ini menggambarkan persamaan regresi untuk mengetahui angka konstan dan uji hipotesis signifikansi koefisien regresi. Persamaan regresinya, dimana:

Y: Subjek dalam variabel bebas (Pengambilan Keputusan)

X1: Variabel X1 (Terpaan Pemeritaaan Media Online)

X2: Variabel X2 (Word of Mouth Communications)

A: Angka konstan dari Unstandardized Coefficient

Berdasarkan hasil uji analisis regresi berganda dari tabel diatas diperoleh bentuk persamaan regresi linear berganda sebagai berikut:

$$
\mathrm{Y}=3.324+0,802 \times 1+0,226 \times 2
$$

Nilai koefisien regresi pada variabel-variabel bebasnya menggambarkan apabila diperkirakan variabel bebasnya naik sebesar satu unit dan nilai variabel bebas lainnya diperkirakan konstan atau sama dengan nol, maka nilai variabel terikat diperkirakan bisa naik atau bisa turun sesuai dengan tanda koefisien regresi variabel bebasnya. Dari persamaan regresi linear berganda diatas diperoleh nilai konstanta sebesar 3.324, artinya jika variabel Pengambilan keputusan (Y) tidak dipengaruhi oleh kedua variabel bebasnya (terpaan pemberitaan media online dan Word of Mouth Communications bernilai 0), maka besarnya rata-rata variabel Pengambilan Keputusan akan bernilai 3.324. Tanda koefisien dari regresi variabel bebas X1 menunjukkan arah hubungan dari variabel yang bersangkutan dengan Pengambilan Keputusan.
Koefisien regresi untuk variabel bebas terpaan pemberitaan media online (X1) bernilai positif, hal ini menunjukkan adanya hubungan yang searah antara terpaan pemberitaan media online (X1) dan Pengambilan Keputusan (Y). Koefisien regresi variabel X1 sebesar 0,802 mengandung arti untuk setiap penambahan nilai terpaan berita (X1) sebesar satu satuan akan menyebabkan meningkatnya pengambilan keputusan (Y) sebesar 0,802. Tanda koefisien dari regresi variabel bebas X2 menunjukkan arah hubungan dari variabel yang bersangkutan dengan Pengambilan Keputusan. Koefisien regresi untuk (X2) bernilai positif, hal ini menunjukkan adanya hubungan yang antara Word of Mouth Communications (X2) dan Pengambilan Keputusan (Y). Koefisien regresi variabel X2 sebesar 0,226 mengandung arti untuk setiap penambahan nilai Word of Mouth Communications (X2) sebesar satu satuan akan menyebabkan naiknya Pengambilan Keputusan (Y) sebesar 0,117.

\section{Uji F}

\begin{tabular}{|l|l|r|l|l|l|}
\hline \multicolumn{7}{|c|}{ Tabel 10: Uji F } \\
\hline $\begin{array}{l}\text { Model } \\
\text { Regression }\end{array}$ & $\begin{array}{l}\text { Sum of } \\
\text { Squares }\end{array}$ & Df & $\begin{array}{l}\text { Mean } \\
\text { Aquare }\end{array}$ & F & Sig \\
\hline Residual & 446.6013 & 2 & 2122.457 & 464.135 & $.000 \mathrm{a}$ \\
\hline \multicolumn{1}{|c|}{ Total } & 4691.515 & 102 & 44.66 & & \\
\hline
\end{tabular}

a. Predictor : (Constant) : terpaan pemberitaan media online, Word of Mouth Communications

b. Dependent Variabel: Pengambilan Keputusan

Sumber: Hasil olah data penulis

Tabel diatas menunjukkan besarnya angka probabilitas atau signifikansi perhitungan Anova digunakan untuk uji kelayakan model regresi dengan ketentuan angka probabilitas yang baik 
untuk digunakan sebagai model regresi ialah harus lebih kecil dari 0,05. Uji Anova menghasilkan angka $F$ sebesar 464.135 dengan tingkat signifikansi (angka probabilitas) sebesar 0,000. Karena angka probabilitas $0,000<0,05$, maka model regresi ini sudah layak untuk digunakan dalam memprediksi terpaan pemberitaan media online dan Word of Mouth Communications. Untuk dapat digunakan sebagai model regresi dapat digunakan dalam memprediksi variabel tergantung, maka signifikansi atau probabilitas (sig) harus $<0,05$.

F Hitung dalam penelitian ini sebesar 464.135 dan $\mathrm{F}$ tabel dalam penelitian ini:

$$
\begin{aligned}
\text { DF1 } & =\mathrm{K}-1 \\
& =3-1=2 \\
\text { DF2 } & =\mathrm{N}-\mathrm{K} \\
& =30-3=27
\end{aligned}
$$

Ditemukan dalam $F$ tabel sebesar 3,35 jadi $F$ Hitung > F Tabel, $464.135>3,35$. Hal ini berarti Ho ditolak dan Ha diterima, yang menunjukkan bahwa terpaan pemberitaan media online dan Word of Mouth Communications. berpengaruh terhadap Pengambilan Keputusan.

\section{Uji T}

Dengan menggunakan tabel 1 Coefficient menunjukkan hasil uji t dimana digunakan untuk menguji signifikansi pengaruh secara parsial dapat diperoleh dengan menggunaka uji T. Ini adalah hasil uji masing-masing variabel secara parsial.

1. Variabel Terpaan Pemberitaan Media Online, Untuk Nilai t dari variabel terpaan pemberitaan sebesar 16,822 dengan nilai signifikansi 0.00. Dengan nilai signifikansi lebih kecil dari 0.05 menunjukkan bahwa Ho ditolak dan $\mathrm{Ha}$ diterima yang berarti terpaan pemberitaan media online memiliki pengaruh yang signifikan terhadap Pengambilan Keputusan.

2. Variabel Word of Mouth Communications, Untuk nilai $\mathrm{t}$ dari variabel Word of Mouth Communications sebesar 3.324 dengan nilai signifikansi 0.003 . Dengan nilai signifikansi lebih kecil dari 0.05 menunjukkan bahwa Ho ditolak dan Ha diterima yang memiliki arti Word of Mouth Communications memiliki pengaruh yang signifikan terhadap Pengambilan Keputusan.

\section{SIMPULAN}

Dalam teori Uses and Gratifications menjelaskan bahwa masyarakat aktif mencari media yang paling baik dalam menyampaikan pesan. Media yang dianggap mampu memberikan kepuasan informasi. Dalam penelitian ini masyarakat aktif memilih media online yang dianggap mampu memberikan kepuasan akan informasi yang dibutuhkan khalayak tentang pengurangan penggunaan plastik dalam kehidupan sehari-hari. Dampak yang ditimbulkan akibat penggunaan plastik bagi kelangsungan hidup dan ekosistem. Pengetahuan tentang pengurangan penggunaan plastik ini, diharapkan dapat dibagikan kepada orang-orang terdekat melalui kegiatan word of mouth communications agar semakin banyak khalayak yang memahami dan menjalankan program pemeritah untuk melakukan pengurangan penggunaan plastik pada saat berbelanja. Semakin banyak informasi yang didapatkan akan semakin mengerti dan mendukung program pemerintah, sehingga 
muncul keinginan untuk mengambil keputusan untuk tidak menggunakan plastik saat berbelanja. Dengan mendukung program pemeritah dapat menciptakan lingkungan yang bersih dan menjamin kelangsungan hidup manusia, hewan dan binatang.

Dalam penelitian ini didapatkan hasil terdapat pengaruh yang sangat kuat antara terpaan pemberitaan media online terhadap Pengambilan Keputusan yaitu dengan koefisien korelasi sebesar 0,888 .

Ada pengaruh yang kuat antara Word of Mouth Communications terhadap Pengambilan Keputusan yaitu dengan koefisien korelasi sebesar 0,743 .

Ada pengaruh yang kuat antara terpaan pemberitaan media online dan Word of Mouth Communications terhadap Pengambilan Keputusan sebesar 0,709. Melalui hasil uji hipotesis dengan uji F secara simultan didapatkan nilai 464.135 membuktikan bahwa hipotesis peneliti Ha diterima dan Ho ditolak yaitu terdapat pengaruh terpaan berita online dan Word of Mouth Communications terhadap Pengambilan Keputusan.

\section{DAFTAR PUSTAKA}

\section{Book}

Ardianto E, Erdinaya dan Lukiati K. (2005). Komunikasi Massa: Suatu Pengantar. Bandung: Simbiosa Rekatama Media.

Ashenfelter O, Levine PB, Zimmerma DJ. (2003). Statistics and Econometrics: Methods and Applications. New York: John Wiley \& Sons, Inc.
Babbie E. (1992). The Practice of Social Research. Belmont, California: Wadsworth Publishing Company.

Bungin B. (2008). Metodologi Penelitian Kuantitatif. Jakarta: Kencana Prenada Media Group.

Carey. (1998). Handbook of New Media: Studen Edition, Leah A. Lievrouw Sonia Livingstone Published.

Derry M. (2013). Pengaruh Kredibilitas Berita Politik Dalam Media Online Okezone.com Terhadap Preferensi Penguna. Penulisan Ilmiah. Jakarta: Universitas Gunadarma.

Kotler, Philip \& Kevin Lane Keller. (2009). Manajemen Pemasaran Edisi 13 Jilid 1. Jakarta:Erlannga.

Kriyantono R. 2007. Teknik Praktis Riset Komunikasi. Jakarta: Kencana Prenada Media Group.

Nugraha, Marza Riyandika. (2013). Analisa Pengaruh Electronic Word-of-Mouth, Argument Quality, Message Source Credibility Terhadap Brand Image dan Dampaknya Pada Purchase Intention. Jakarta : Binus University.

Ruggerio. (2000). Mass Communications and Society. Texas University at El Paso.

Rusdiana A. (2016). Pengembangan Organisasi Lembaga Pendidikan. Bandung Pustaka Setia.

\section{Jurnal online}

Kadir. (2012). Kajian Pemanfaatan Sampah Plastik Sebagai Sumber Bahan Bakar Cair. Volume 3 N0 2 Mei 2012. Dinamika Jurnal Ilmiah Teknik Mesin.

Mustika Rieka. (2017). Analisis Framing Pemberitaan Media Online Mengenai Kasus PedoFilia Di Akun Facebook. Jurnal Penelitian komunikasi Volume 20 N0 02 Desember 2017. http://bppkibandung,id/index.php/jpk.

Situmeang Ilona Vicenovie Oisina, Girsang Lasmery. (2016). Pengaruh Terpaan Pemberitaan Di Media Dan Daya Tarik Iklan Layanan Masyarakat Dimedia Internet Terhadap Tingkat Pengetahuan Khalayak Tentang Penggunaan Sampah Plastik. Penelitian Internal Dosen UMB, Jakarta. 
Surono UB. (2013). Berbagai Metode Konversi Sampah Plastik Menjadi Bahan Bakar Minyak. Jurnal Teknik. Volume 2 No 1 April 2013

\section{Surat Kabar Online}

TEMPO.Co, Denpasar, Senin, 24 Desember 2018 11:32 WIB 